J. Kundrák, I. Sztankovics, F. Lukács, Miskolc, Hungary

\title{
COMPARATIVE ANALYSIS OF HARD MACHINED BORES BASED ON THE ROUGHNESS AND ACCURACY
}

\begin{abstract}
The results of a comparative study on the machining of hard machined surfaces are presented in this paper. We compared the surface roughness, roundness and cylindricity errors of bores machined by grinding, hard turning and a combined procedure. Based on the results we ranked the studied procedures to help in decision making in process planning.
\end{abstract}

Keywords: functional properties; surface roughness; accuracy parameters; turning; grinding; combined procedures.

\section{INTRODUCTION}

Accurate and effective machining is high priority in the large series production of wheel-like parts with hardened surfaces, because such parts belong to this group as the gears in gearboxes. These products are machined on a scale of millions. It can be concluded by the analysis of the functional properties of these parts that the two determining surfaces are the gearing and the bore.

In this study we analysed the machining of the bores. The prescribed accuracy and quality requirements for the bores were earlier assured by grinding. Grinding is capable of fulfilling the requirements; however, it can be considered low productivity due to the low material removal rate. Meanwhile, the technology applied in the production chain was switched from surface hardening only of the gearing to case hardening the whole gear wheel.

Grinding finishing made the applied technology more complex, since more machines are needed for the precision machining of the bores and flat surfaces; therefore, the workpiece could only be completed in several clampings. This problem encouraged the introduction of a solution in which all of the functional surfaces of the gear wheels can be machined in one clamping.

An excellent solution for this approach is hard turning [1,2], where the production is granted by a hard turning lathe specifically designed for this purpose and the application of a super hard cutting tool (cubic boron nitride inserts). Grinding and turning have different advantages in the production of workpiece surfaces. In hard turning, the material or allowance removal is 4-5fold more efficient than in grinding [3, 4, 5]. Different signs of the stress can be observed in the surface layer; furthermore, the characteristics of the surface topography are also different.

(C) J. Kundrák, I. Szztankovics, F. Lukács, 2020 
With that in mind, the goal was not only to allow machining in one clamping with the combination of the two procedures, but to maintain the advantages of the two procedures while reducing the disadvantageous attributes as much as possible [6]. In this study we performed a comparative analysis of the machining of gear wheel bores with three procedures, comparing the surface roughness and the accuracy parameters.

\section{EXPERIMENTAL CONDITIONS}

The bore machining is done on an EMAG VSC 400 DS type hard turning centre. The bore of a gear wheel workpiece with $88 \mathrm{~mm}$ inner diameter was machined on 38 $\mathrm{mm}$ length. The material grade of the workpiece was $20 \mathrm{MnCr} 5$ steel with hardness of 62-64 HRC. The following tools were used in the machining: Sandvik CCGW 09T308 NC2 insert with a E25T-SCLCR 09-R tool holder for the turning; Norton 3AS80J8VET 01_36X37X13 grinding wheel for the grinding.

The allowance after the heat treatment was removed by grinding (GR), by hard turning with three feed rates (HT1, HT2, HT3) and by the combination of these procedures: roughing with hard turning, finishing with grinding $(\mathrm{CB})$. The difference in the combination of the two procedures from the usual approach (roughing with defined edge geometry and grinding after this) is that the machining was done with one machine and in one clamping, meaning that the workpiece time and the possibility of clamping inaccuracy can be lowered. The procedure variants and the adjusted cutting parameters are summarised in Table 1.

Table 1 - The studied procedure variant and process parameters

\begin{tabular}{|c|c|c|c|c|c|}
\hline Notation & $\begin{array}{c}\text { Operation } \\
\text { elements }\end{array}$ & $\begin{array}{c}\mathbf{a} \\
{[\mathbf{m m}]}\end{array}$ & $\begin{array}{c}\mathbf{f} \\
{[\mathbf{m m}]}\end{array}$ & $\begin{array}{c}\mathbf{n}_{\mathbf{t}} \\
{[\mathbf{1} / \mathbf{m i n}]}\end{array}$ & $\begin{array}{c}\mathbf{n}_{\mathbf{w}} \\
{[\mathbf{1} / \mathbf{m i n}]}\end{array}$ \\
\hline $\boldsymbol{G R}$ & grinding & 0.2 & 0.01 & 20000 & 325 \\
\hline $\boldsymbol{H T 1}$ & turning & 0.2 & 0.1 & - & 615 \\
\hline $\boldsymbol{H T 2}$ & turning & 0.2 & 0.2 & - & 617 \\
\hline $\boldsymbol{H T 3}$ & turning & 0.2 & 0.3 & - & 617 \\
\hline \multirow{2}{*}{$\boldsymbol{C B}$} & turning & 0.15 & 0.2 & - & 615 \\
\cline { 2 - 6 } & grinding & 0.05 & 0.01 & 20000 & 325 \\
\hline
\end{tabular}

\section{EXPERIMENTAL RESULTS AND DISCUSSION}

The bore machining experiments were carried out in the following order on different parts: grinding (GR), hard turning with three feeds (HT1, HT2, HT3), and the combined procedure (CB). The $R_{a}, R_{z}$ and $R_{q}$ roughness values were measured on three generatrix of the cylindrical surface, the mean values of the measurements were calculated (Table 2) and the roughness profiles were recorded (Table 3 ). 
ISSN 2078-7405. Різання та інструменти в технологічних системах, 2020, випуск 92

Table 2 - Mean values of the measured surface roughness parameters

\begin{tabular}{|c|c|c|c|c|c|}
\hline & GR & HT1 & HT2 & HT3 & CB \\
\hline $\mathrm{R}_{\mathrm{a}}[\mu \mathrm{m}]$ & 0.636 & 0.406 & 0.460 & 1.103 & 0.410 \\
\hline $\mathrm{R}_{\mathrm{z}}[\mu \mathrm{m}]$ & 4.503 & 2.083 & 3.56 & 5.643 & 3.081 \\
\hline $\mathrm{R}_{\mathrm{q}}[\mu \mathrm{m}]$ & 0.806 & 0.483 & 0.603 & 1.356 & 0.516 \\
\hline
\end{tabular}

Table 3 - Roughness profiles of the machined surfaces

GR


After the roughness measurements, the characteristic parameters of the bore accuracy were measured:

STRt difference of the generatrix of the evaluated surface from a line

RONt roundness error of the evaluated surface in an intersecting plane

CYLt cylindricity error of the evaluated surface

CYLtt conicity error of the evaluated surface

Cone Angle cone angle of the evaluated surface

The results are summarised in Table 4 .

Table 4 - Results of the accuracy error measurements

\begin{tabular}{|l|c|c|c|c|c|}
\hline & GR & HT1 & HT2 & HT3 & CB \\
\hline STRt $[\mu \mathrm{m}]$ & 5.81 & 2.15 & 1.76 & 1.7 & 4.54 \\
\hline RONt $[\mu \mathrm{m}]$ & 8.48 & 6.24 & 5.18 & 9.44 & 5.15 \\
\hline CYLt $[\mu \mathrm{m}]$ & 44.93 & 16.27 & 10.9 & 18.12 & 27.75 \\
\hline CYLtt $[\mu \mathrm{m}]$ & 70.71 & 22.31 & 12.19 & 18.83 & 44.79 \\
\hline${\text { Cone angle }\left[{ }^{\circ}\right]}$ & 0.1392 & 0.0305 & 0.0203 & 0.0208 & 0.0777 \\
\hline
\end{tabular}

We conclude based on the analysis of the roughness values that values corresponding to the roughness of the ground surface can be achieved by hard turning with 0.1 and 0.2 feed. If we would like to obtain the acquirable roughness with grinding, 0.3 feed cannot be chosen for hard turning. Another attribute that we must think about when choosing procedures is the characteristic of the generated topography. Particularly surfaces with higher roughness show the periodic character of the profile in hard turning. Due to this fact, the turned surface cannot be suggested despite its good roughness values if the functional requirements do not allow it.

We can say from the experiments that low roughness values and random surface topography can be assured with the combined procedure. The comparison of more parameters (for example the productivity of surface machining) is not the subject of this analysis, but we know from our earlier studies that the combined procedure is more efficient than grinding due to the productivity of the rough turning, and the environmental load is also lower due to the lower grinding allowance.

The achievable accuracy was also compared to that of grinding (Figure 1). 

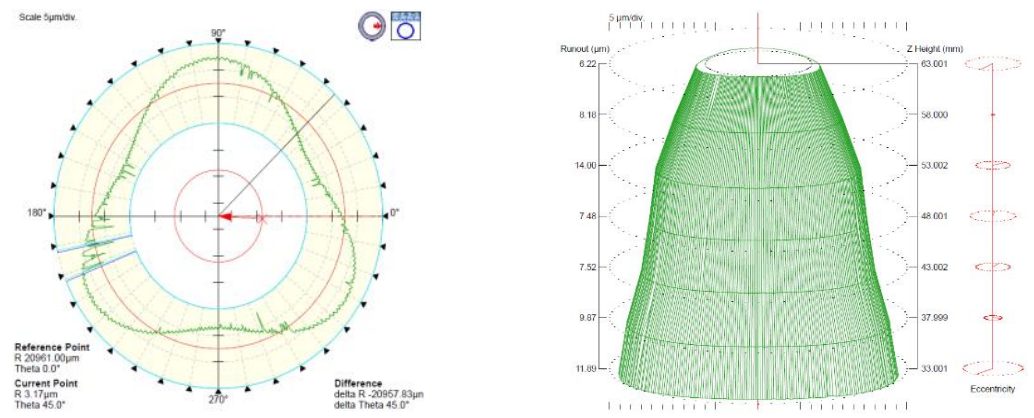

Figure 1 - Roundness error and cylindricity - ground surface

The following remarks can be said after the analysis. The roundness error is lower than grinding by $30 \%$ at 0.1 feed and by $40 \%$ at 0.2 feed; however, it is higher by $10 \%$ at 0.3 feed (Figure 3). With the application of the combined procedure, the RONt value decreased by $3.3 \mu \mathrm{m}$ or $40 \%$ (Figure 2). The cylindricity error on the only turned surfaces is between half and quarter of the cylindricity of ground bores. In the case of the combined procedure the decrease is $17 \mu \mathrm{m}$ (or $40 \%$ ) from the studied value. For the conicity and cone angle we say that the decrease from the values of grinding is $83-69 \%$ in conicity and $86-78 \%$ in thecone angle in hard turning We measured a smaller decrease $(40 \%)$ in the combined procedure from the grinding. We determine from these numbers that the shape error is lower in the application of turning (except for 1 roundness error value), therefore the allowance to be removed in the finishing operation can even be lowered, which would result in a further decrease in the main machining time.
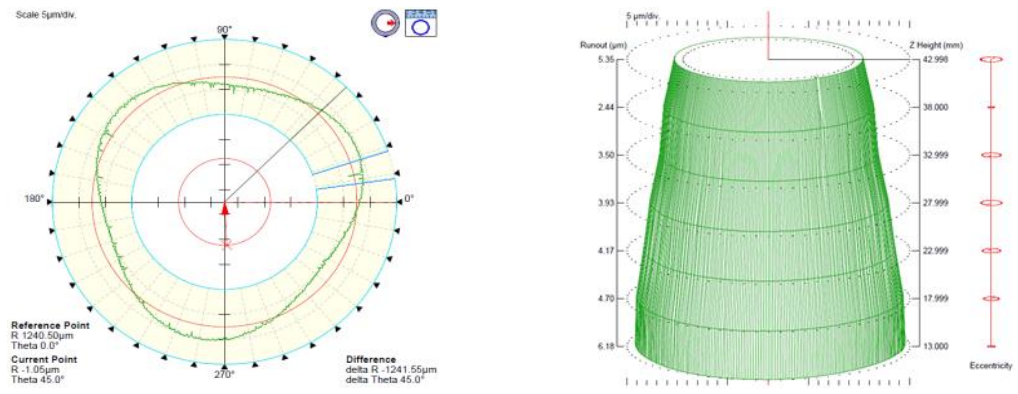

Figure 2 - Roundness error and cylindricity - combined procedure 


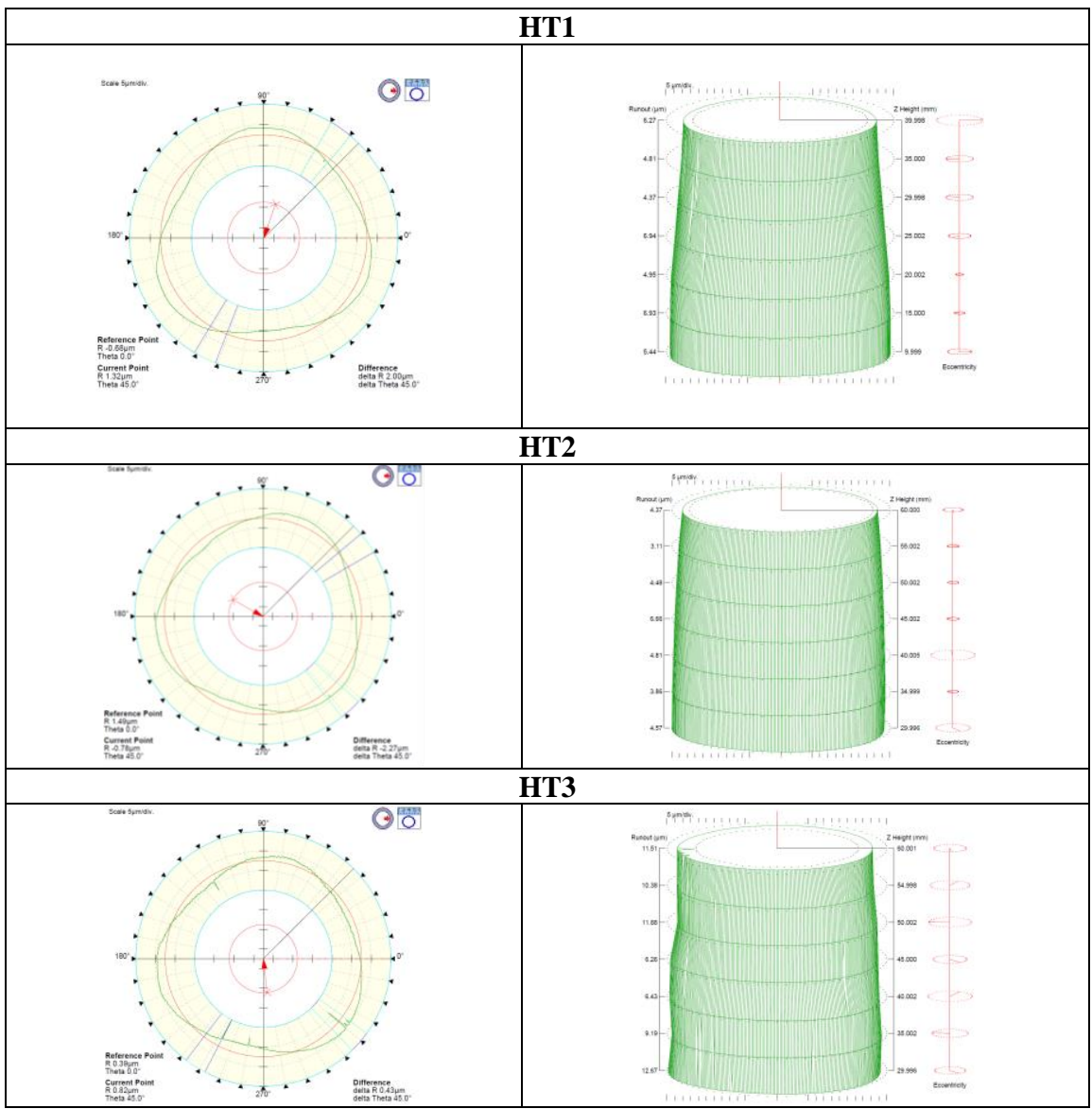

Figure 3 - Roundness error and cylindricity - hard turned surface

\section{SUMMARY}

The substitutability of finishing done by grinding (in most cases) is analysed with other machining procedures in this paper by the comparison of roughness and accuracy parameters. We determined that the same or better values of ground surface can be produced by hard turning (up to $0.2 \mathrm{~mm}$ feed) and by the combined procedure. Taking into consideration our earlier results, we advise the substitution of grinding with the studied procedures based on the material removal efficiency. If the production of random surfaces is needed, then the combined procedure is better, otherwise the hard turning procedure is the better choice. 


\title{
ACKNOWLEDGEMENT
}

The described study was carried out as part of the EFOP-3.6.1-16-00011 "Younger and Renewing University - Innovative Knowledge City institutional development of the University of Miskolc aiming at intelligent specialisation" project implemented in the framework of the Szechenyi 2020 program. The realization of this project is supported by the European Union, co-financed by the European Social Fund.

References: 1. Kundrák, J.: The scientific principles of increasing the effectiveness of inner surfaces cutting with CBN tools. Harkov, p. 368, 1996. 2. Byrne, G., Dornfeld, D., Denkena B.: Advancing Cutting Technology. CIRP Annals 52(2), pp. 483-507, 2003. 3. Bartarya, G., Choudhury S.K.: State of the art in hard turning, International Journal of Machine Tools and Manufacture, 2011. 4. Kundrák, J.: Alternative machining procedures of hardened steels, Manufacturing technology 11, 32-39. 5. Samantaraya, D., Lakade, S., Keche, A.: An Alternate Machining Method for Hardened Automotive Gears. Procedia Manufacturing 20 (2018) 517-522. 6. Kundrak, J., Varga, G., Deszpoth, I., Molnar, V.: Some aspects of the hard machining of bore holes. Applied Mechanics and Materials, 309, pp. 126-132 (2013).

\author{
Янош Кундрак, Іштван Станкевіч, Ференц Лукач, \\ Мішкольц, Угорщина
}

\section{ПОРІВНЯЛЬНИЙ АНАЛІЗ ВАЖКООБРОБЛЮВАНИХ ОТВОРІВ НА БАЗІ ШОРСТКОСТІ І ТОЧНОСТI}

\begin{abstract}
Анотація. У иьому дослідженні були проаналізовані результати обробки отворів зубчастих коліс різними методами. Була зроблена спроба об'єднати два прочеси різання: точіння та шиіфування на одному верстаті $i$ з однієї установки заготовки. Припуск після термообробки був видалений шліфуванням та жорсткою токарною обробкою з трьома швидкостями подачі $і$ поєднанням иих прочедур: чорнова обробка з жорсткою токарною обробкою, чистова обробка з шліфуванням. Відмінність у комбінаиії двох прочедур від звичайного підходу (чорнова обробка з певною геометрією різия та шліфування після цього) полягає в тому, що обробка виконувалась на одному верстаті $i$ з однієі установки, щуо означає, щчо час переустановлення деталі і можсливість неточності затиску можуть бути опущеними. Після вимірювання шорсткості були виміряні характерні параметри точності отвору: нелінійність твірної ииліндра, помилка круглості отвору в січній площині, нецилиндричность (конусність). 3 експериментів можна сказати, що низькі значення шорсткості $і$ прогнозована топографія поверхні можуть бути забезпечені за допомогою комбінованої процедури. 3 більш ранніх досліджень параметра продуктивності обробки відомо, що комбінована прочедура більи ефективна, ніж шиліфування, з-за більш високої продуктивності чорнового точіння та шкода довкіллю також нижче з-за меншого припуску на шліфування. Замінність чистової обробки, виконуваної шиіфуванням (в більшості випадків), аналізується з допомогою інших методів обробки, наведених у иій статті, иляхом порівняння параметрів шорсткості і точності. Зазначено, щчо такі ж або кращі значення параметрів поверхні можуть бути отримані иляхом точного точіння (подача до 0,2 мм) $i$ комбінованою процедурою. Беручи до уваги отримані результати, можно радити заміну шліфування на вивчені прочедури, засновані на ефективності видалення матеріалу. Якщо необхіно отримання прогнозованої топографії поверхні, тоді краще використовувати комбіновану процедуру.
\end{abstract}

Ключові слова: функціональні властивості; иорсткість поверхні; параметри точності; точіння; иліфування; комбіновані процедури. 